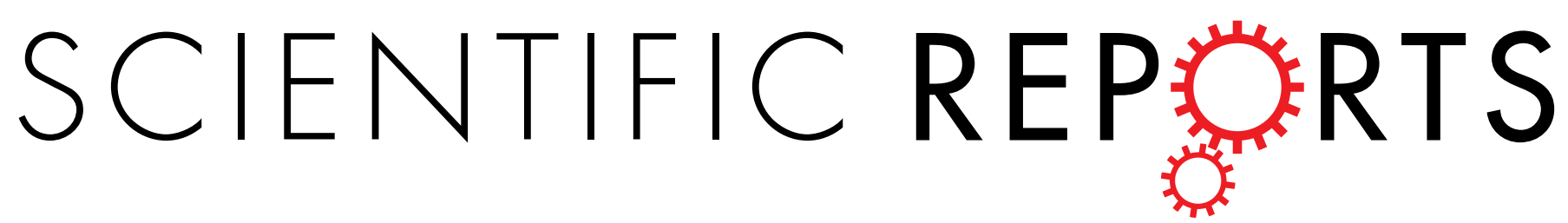

\title{
OPEN Corrigendum: Drosophila Rif1 is an essential gene and controls late developmental events by direct interaction with PP1-87B
}

Easwaran Sreesankar, Vellaichamy Bharathi, Rakesh K. Mishra \& Krishnaveni Mishra

Scientific Reports 5:10679; doi: 10.1038/srep10679; published online 29 May 2015; updated on 09 February 2016

In the Supplementary Information file originally published with this Article, Figures S3 and Figure S8 were omitted. In addition, Figures S4, S5, S6 and S7 were incorrectly labelled as Figures S3, S4, S5 and S6 respectively. These errors have now been corrected in the Supplementary Information that now accompanies the Article.

(c) (1) This work is licensed under a Creative Commons Attribution 4.0 International License. The images or other third party material in this article are included in the article's Creative Commons license, unless indicated otherwise in the credit line; if the material is not included under the Creative Commons license, users will need to obtain permission from the license holder to reproduce the material. To view a copy of this license, visit http://creativecommons.org/licenses/by/4.0/ 